\title{
Assessment of Groundwater Quality for Drinking Purpose by Using Water Quality Index (WQI) in Muzaffarnagar and Shamli Districts, Uttar Pradesh, India
}

\author{
Gopal Krishan", Surjeet Singh, Kumar CP, Garg PK, Suman Gurjar, Ghosh NC and Anju Chaudhary \\ National Institute of Hydrology, Roorkee-247 667, Uttarakhand, India \\ *Corresponding author: Dr. Gopal Krishan, Scientist-C, National Institute of Hydrology, Roorkee-247 667, Uttarakhand, India, Tel: 09634254939; E-mail: \\ drgopal.krishan@gmail.com
}

Rec date: Jan 21, 2016; Acc date: Feb 11, 2016; Pub date: Feb 20, 2016

Copyright: $\odot 2016$ Krishan G, et al. This is an open-access article distributed under the terms of the Creative Commons Attribution License, which permits unrestricted use, distribution, and reproduction in any medium, provided the original author and source are credited.

\begin{abstract}
A water quality index (WQI) numerically summarizes the information from multiple water quality parameters into a single value that is understandable and usable by the public. This information can be used to assess spatial and temporal variations in overall water quality. However, these indices are time and region specific and may be influenced by local factors. Muzaffarnagar and Shamli districts of Uttar Pradesh are situated in Ganga-Yamuna doab of fertile alluvium of Indo-gangetic basin where the demands for surface water and groundwater are growing with rapid increase in agricultural and industrial activities. In the present study, water quality index is worked out to assess the spatial variation of groundwater quality status for future planning and management of Muzaffarnagar and Shamli districts using WQI. Data of 104 groundwater samples covering the whole districts have been used. The Water Quality Index has been computed using five parameters viz., pH, Total Dissolved Solids, Total Hardness, Chloride and Sulphate. The WQI results show that the overall water quality class is 'good' and water is acceptable for domestic use.
\end{abstract}

Keywords: Water quality index; Groundwater Muzaffarnagar; Shamli; Uttar Pradesh; Indo-Gangetic plains

\section{Introduction}

Increasing demand for domestic and irrigation purposes and imprudent use of groundwater has put its sustainability in danger due to its continuous depletion and deterioration of quality in northwest India [1-13] and Indo-Gangetic basin [14-16]. The water quality evaluations have been carried out by various researchers in various parts of India using different methods [17-23]. Generally, water samples are analysed for a number of water quality parameters to assess its suitability for drinking and irrigation purposes. A water quality index (WQI) numerically summarizes the information easily from multiple water quality parameters into a single value that can be used to assess spatial and temporal variations in overall water quality. The WQI has been developed for surface water by many researchers [24-28] but the efforts are being made to work out these indices for the groundwater also in Indo-Gangetic plains and has already been computed for Haridwar district of Uttarakhand [29].

The Muzaffarnagar and Shamli districts of Uttar Pradesh are situated in Ganga-Yamuna doab of fertile alluvium of Indo-gangetic basin and are bounded by Saharanpur district in the north, Haridwar district of Uttarakhand in the northeast, Bijnor district in the east, Meerut district in the south and river Yamuna separates it from the adjoining state of Haryana in the west. The eastern boundary of the districts with Bijnor district is formed by river Ganga. The districts occupy the northern part of Ganga-Yamuna basin with Ganga being in the east and Yamuna in the west of the districts.

The Muzaffarnagar and Shamli districts have many industries generating considerable toxic effluents which might contaminate groundwater of these districts in future. Groundwater quality of these districts shows high concentrations of $\mathrm{Cl}^{-}$and $\mathrm{SO}_{4}^{2}{ }_{4}^{-}$that are generally due to anthropogenic activities, which may be local in nature [8].

Though water quality evaluations were done by Tyagi et al. [30] in the area but Water Quality Index (WQI) was not developed. Keeping this in view, the present work carried with the overall objectives (i) to assess the suitability of groundwater for drinking purpose, as per the guidelines reported by Singh et al. [31] in Muzaffarnagar and Shamli districts, Uttar Pradesh, India computing Water Quality Index (WQI) tool, (ii) to categorize the groundwater quality samples for drinking purpose.

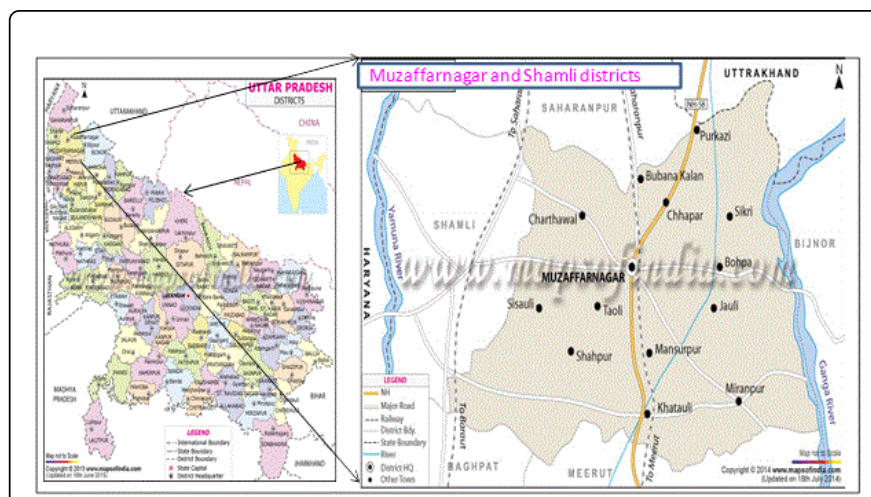

Figure 1: Location map of study area. 
Citation: Krishan G, Singh S, Kumar CP, Garg PK, Suman G, et al. (2016) Assessment of Groundwater Quality for Drinking Purpose by Using Water Quality Index (WQI) in Muzaffarnagar and Shamli Districts, Uttar Pradesh, India. Hydrol Current Res 7: 227. doi: $10.4172 / 2157-7587.1000227$

Page 2 of 4

\section{Study Area}

The study was carried out in Muzaffarnagar and Shamli districts of Uttar Pradesh. Shamli district was carved out from Muzaffarnagar district in 2011 and the study area lies between $29^{\circ} 01^{\prime} 50^{\prime \prime}-29^{\circ} 44^{\prime} 20^{\prime \prime} \mathrm{N}$ latitude and $77^{\circ} 02^{\prime}-78^{\circ} 07^{\prime} \mathrm{E}$ longitude (Figure 1). Muzaffarnagar and Shamli districts has total geographical area of $4080 \mathrm{~km}^{2}$ i.e., $2810 \mathrm{~km}^{2}$ of Muzaffarnagar comprising of 4 Tehsils and $1070 \mathrm{~km}^{2}$ of Shamli comprising of 2 Tehsils. The study area has an average daily maximum temperature of $40^{\circ} \mathrm{C}$ and average daily minimum temperature of $24^{\circ} \mathrm{C}$, average relative humidity is $67 \%$ and normal rainfall is $753 \mathrm{~mm}$ with $80 \%$ of rainfall occurring in monsoon season (June-September) [32]. The area is characterized under Indo-Gangetic alluvium group of soils and is represented predominately by loamy soils.

CGWB [32] reported that depth to water level in the study area varies between 3.20-9.95 $\mathrm{m}$ during pre-monsoon and $2.50-7.95 \mathrm{~m}$ in post-monsoon with fluctuation varying from $0.70-2.00 \mathrm{~m}$. The stage of groundwater development is $82 \%$.

\section{Methodology}

For computing Water Quality Index (WQI), the groundwater quality data of 104 sampling points (77 sampling points in Muzaffarnagar district and 27 sampling points in Shamli district) covering both the districts (Figure 2) given by Tyagi et al. [30] was used. For calculating the Water Quality Index (WQI), the methods followed by Singh et al. [31] have been employed. In the present study, 5 parameters have been considered to compute WQI. However, considering large number of parameters results more reliable for prediction of WQI but in the present work limited numbers of parameters available as $\mathrm{pH}$, Total Dissolved Solids, Total Hardness, Chloride and Sulphate. The water quality index was calculated using quality rating scale and accordingly assigning the weight values to the selected parameters. The standards of the water quality parameter are governed as per BIS: 10500-2012 and Central Pollution Control Board (CPCB) standards and their respective weight used in the present study are highlighted in Table 1.

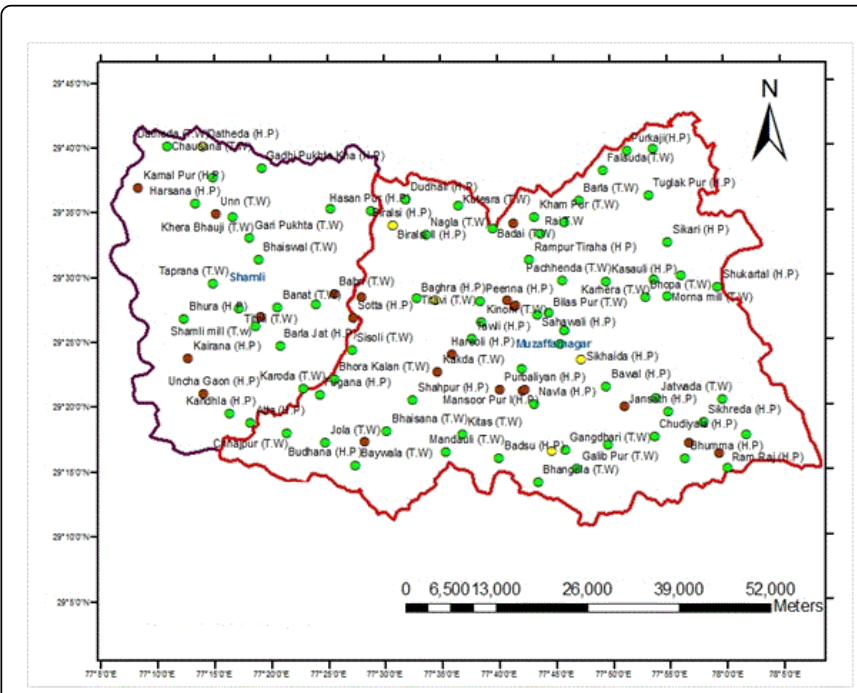

Figure 2: Map showing sampling locations in Muzaffarnagar and Shamli districts, Uttar Pradesh.
Overall Water Quality Index (OWQI) has been developed for surface water by Singh et al. [31] which can also be used for groundwater also [33].

As reported by Singh et al. $[29,31]$ to gauge the influence of each individual parameter on a common single scale, the score generated by each parameter was averaged-out. The following weighted average aggregation function has been used for this purpose.

$$
W Q I=\sum_{i=1}^{n} W_{i} . Y_{i}(1)
$$

Where $\mathrm{w}_{\mathrm{i}}=$ weight of the $\mathrm{i}^{\text {th }}$ water quality parameter and $\mathrm{Y}_{\mathrm{i}}=$ subindex value of the $\mathrm{i}^{\text {th }}$ parameter (As reported by Singh et al. [31] subindices functions are basically the equations that transform the concentration ranges into the index score through mathematical equations. These scores are then further converted to a common scale based on their relative importance to impact the quality of water. These sub-indices function are developed based on the water quality standards and their concentrations to meet in particular range. For this purpose, mathematical expressions were fitted for each parameter to obtain the sub-index equations).

Based on the status of water quality data, the index value ranges from 0 to 100 and is classified into five categories: heavily polluted (0-24), poor (25-49), fair (50-74), good (75-94) and excellent (95-100). The status of water corresponding to different WQI values is presented in Table 2. If the index goes down, then it indicates that some of the water quality parameters are beyond permissible ranges due to some particular reason and suitable measures are needed to improve the quality of water. Thus this index may be used as a guiding rule in management of quality of water resources. Various sub-indices functions and descriptive details are given by Singh et al. [29,31] and have not reported here.

\begin{tabular}{|l|l|l|l|}
\hline S No & Parameter & $\begin{array}{l}\text { Weight } \\
\text { Factor }\end{array}$ & Standards (IS-10500) \\
\hline 1 & $\mathrm{pH}$ & 1 & $6.5-8.5$ \\
\hline 2 & $\begin{array}{l}\text { Total Dissolved Solids } \\
(\mathrm{mg} / \mathrm{l})\end{array}$ & 3 & $500-2000$ \\
\hline 3 & Total Hardness $(\mathrm{mg} / \mathrm{l})$ & 1 & $300-600$ \\
\hline 4 & Chloride $(\mathrm{mg} / \mathrm{l})$ & 1 & $250-1000$ \\
\hline 5 & Sulphate $(\mathrm{mg} / \mathrm{l})$ & 2 & $25-1000$ \\
\hline
\end{tabular}

Table 1: Assignment of significance weight to the water quality parameter [29,31].

\begin{tabular}{|l|l|l|}
\hline Class & WQI Value & Status of Water \\
\hline Heavily Polluted & $0-24$ & Unsuitable for All Purposes \\
\hline Poor & $25-49$ & $\begin{array}{l}\text { Special Treatment (Special } \\
\text { Treatment) }\end{array}$ \\
\hline Fair & $50-74$ & $\begin{array}{l}\text { Needs Treatment (Filtration \& } \\
\text { Disinfection) }\end{array}$ \\
\hline Good & $75-94$ & Acceptable \\
\hline Excellent & $95-100$ & Pristine Quality \\
\hline
\end{tabular}

Table 2: WQI and corresponding class and status of water quality $[29,31]$. 
Citation: Krishan G, Singh S, Kumar CP, Garg PK, Suman G, et al. (2016) Assessment of Groundwater Quality for Drinking Purpose by Using Water Quality Index (WQI) in Muzaffarnagar and Shamli Districts, Uttar Pradesh, India. Hydrol Current Res 7: 227. doi: $10.4172 / 2157-7587.1000227$

Page 3 of 4

\section{Results and Discussion}

The statistical summary of physico-chemical parameters and WQI variation of 104 samples (77 sampling points in Muzaffarnagar district and 27 sampling points in Shamli district) are given in Table 3 and Figure 3, respectively. It is observed that maximum and minimum value of WQI has been found to be 100 and 36.2 delineated 'Excellent' and 'Poor' category, respectively as per the Table 2. In the present study, in Muzaffarnagar district it is observed that majority of groundwater samples i.e., 73\% qualify in the 'Excellent' category and are of pristine quality, $21 \%$ samples fall in 'Good' category and are acceptable for domestic use; 5\% samples qualify in 'Fair' category which needs 'Filtration and disinfection' treatment and 1 sample fall in the 'Poor' category which is unsuitable for all purposes. In Shamli district, $67 \%$ qualify in the 'Excellent' category and are of pristine quality, 26\% samples fall in 'Good' category and are acceptable for domestic use; $7 \%$ samples qualify in 'Fair' category which needs 'Filtration and disinfection' treatment. The groundwater quality is good in both the districts except in some pockets in the central part of the Muzaffarnagar district (Figure 3).

It may also be noted that two parameters, particularly chloride and hardness are found to be higher in most of the samples compared to permissible levels resulting in higher TDS value owing to anthropogenic contribution which might take place in the vicinity of industrial and agricultural areas in the districts Muzaffarnagar and Shamli.

In Haridwar district of Uttarakhand, India similar to this work WQI was computed using seven different quality parameters to assess the suitability of groundwater for drinking purposes and $95 \%$ groundwater samples qualified in the category of 'good to excellent'.

Tiwari et al. [34] reported in a study conducted for developing WQI for groundwater resources in West Bokaro coalfield, India that despite the coal mining and industry, an analysis of the chemistry of 33 dug wells sample indicates it is $79 \%$ of groundwater samples were found as excellent to good category and suitable for drinking purposes.

\begin{tabular}{|l|l|l|l|l|l|}
\hline Parameters & $\mathbf{p H}$ & $\mathbf{m g} / \mathbf{l}$ \\
\cline { 3 - 6 } & & TDS & $\mathbf{C l}^{-}$ & $\mathbf{S O}_{4}{ }^{2-}$ & Total Hardness \\
\hline Muzaffarnagar (n=77) & 7 & 113.9 & 12 & 10.4 & 125.2 \\
\hline Minimum & 8.2 & 5112.1 & 234.7 & 170.1 & 1141.6 \\
\hline Maximum & 7.6 & 547.7 & 71.2 & 39 & 334.2 \\
\hline Average & 0.3 & 597 & 267.1 & 39.3 & 165.4 \\
\hline Std. Deviation & 7.2 & 268 & 15.6 & 14.4 & 133.2 \\
\hline Shamli (n=27) & \multicolumn{5}{|l}{} \\
\hline Minimum & 8.1 & 1353.4 & 144 & 659.7 & 525.1 \\
\hline Maximum & 7.6 & 577.4 & 38.6 & 80.7 & 321.5 \\
\hline Average & 0.2 & 274.5 & 27 & 174.9 & 86.2 \\
\hline Std. Deviation & & & & \\
\hline
\end{tabular}

Table 3: Statistical summary of physico-chemical parameters of groundwater samples $(\mathrm{n}=104)$.
These observations are based on the data of Tyagi et al. [30], where the samples were collected in pre-monsoon season of 2005, so continuous monitoring of groundwater well is required in the study area to assess the recent groundwater status for drinking purpose using water quality index. For this, a groundwater monitoring network should be designed and planned scientifically in the study area [35].

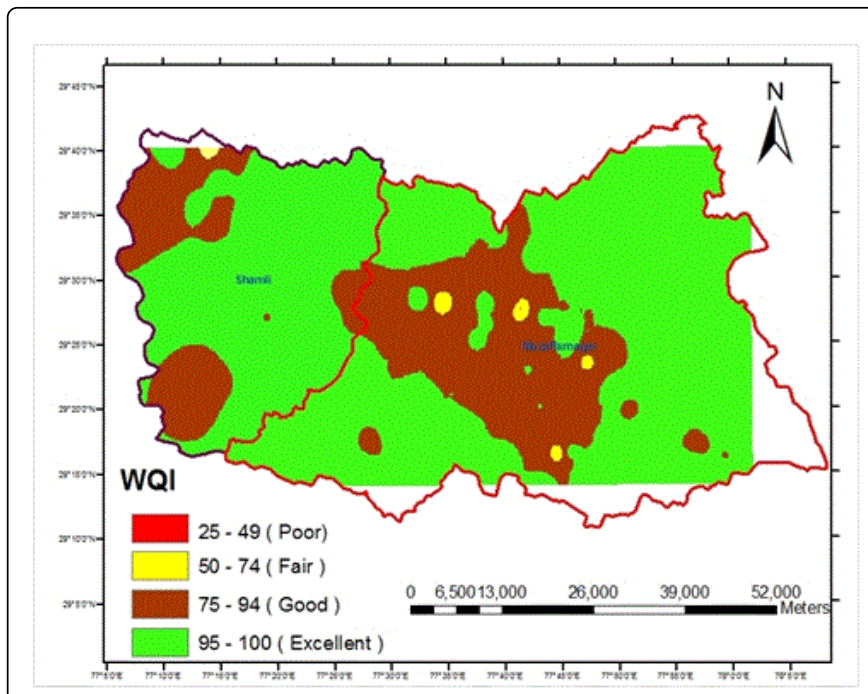

Figure 3: Spatial variation of water quality index in groundwater samples of Muzaffarnagar and Shamli districts, Uttar Pradesh.

\section{Conclusions}

WQI has been computed based on five different quality parameters to assess the suitability of groundwater for drinking purposes in Muzaffarnagar and Shamli districts, Uttar Pradesh. The results show that overall $71 \%$ groundwater samples are of pristine quality; $22 \%$ fall in the category of 'good'; $6 \%$ groundwater samples require treatment and 1 sample is found to be unsuitable for all purposes. This study concludes that 97 groundwater samples are suitable as per drinking standard and remaining 7 groundwater samples are not fit for drinking due to lesser WQI value of $\leq 75$. The groundwater quality is good in both the districts except in some pockets in the central part of the Muzaffarnagar district.

Though the present WQI is based on five parameters, as per the available data, there is a need to include more water quality parameters for the assessment. The continuous monitoring of groundwater is required in Muzaffarnagar and Sahmli districts, Uttar Pradesh to get the recent groundwater quality status for better human health and economic development and also to check any possible contamination in future due to growing industrialization and agricultural activities in the district. A re-assessment of the WQI based on recent data will be useful in proper management of the water resources in these districts.

\section{Acknowledgements}

Authors thank Director, National Institute of Hydrology for all the support and encouragement. 
Citation: Krishan G, Singh S, Kumar CP, Garg PK, Suman G, et al. (2016) Assessment of Groundwater Quality for Drinking Purpose by Using Water Quality Index (WQI) in Muzaffarnagar and Shamli Districts, Uttar Pradesh, India. Hydrol Current Res 7: 227. doi: $10.4172 / 2157-7587.1000227$

Page 4 of 4

\section{References}

1. Chopra RPS, Krishan G (2014) Analysis of aquifer characteristics and groundwater quality in southwest Punjab, India. Journal of Earth Science and Engineering 4: 597-604.

2. Chopra RPS, Krishan G (2014) Assessment of groundwater quality in Punjab. Journal of Earth Science and Climate Change 5: 243.

3. Krishan G, Rao MS, Loyal RS, Lohani AK, Tuli NK, et al. (2014) Groundwater level analyses of Punjab, India: A quantitative approach. Octa Journal of Environmental Research 2: 221-226.

4. Krishan G, Lapworth DJ, Rao MS, Kumar CP, Smilovic M, et al. (2014) Natural (Baseline) Groundwater Quality In The Bist-Doab Catchment, Punjab, India: A Pilot Study Comparing Shallow and Deep Aquifers. International Journal of Earth Sciences and Engineering 7: 16-26.

5. Krishan G, Rao MS, Purushothaman P, Rawat YS, Kumar CP, et al. (2014) Groundwater Resources in Bist-Doab Region, Punjab, India-an overview. NDC-WWC Journal 3: 5-13.

6. Krishan G, Lohani AK, Rao MS, Kumar CP (2014) Prioritization of groundwater monitoring sites using cross-correlation analysis. NDCWWC Journal 3: 28-31.

7. Krishan G, Singh RP, Takshi KS (2015) Water Level Fluctuation as the Sum of Environmental and Anthropogenic Activities in Southeast, Punjab (India). Journal of Environmental and Analytical Toxicology 5: 298.

8. Krishan G, Singh RP, Khanna A, Singh S, Ghosh NC (2015) Recent groundwater status of groundwater in Haridwar district, Uttarakhand. In: Proceedings of National Seminar on R \& D Perspective for Rejuvenation of River Ganga during 16-17 December, 2015 at NIH, Roorkee. Pp: 12-13.

9. Krishan G, Singh S, Sharma A, Sandhu C, Grischek T, et al. (2015) Assessment of river quality for river bank filtration along Yamuna River in Agra-Mathura districts of Uttar Pradesh”. In: Proceedings of National conference on Monitoring and Management of Drinking Water Quality (MMDWQ) \& XXVIII annual conference of National Environment Science Academy during 21-23 December, 2015 at UCOST, Dehradun.

10. Lapworth DJ, Krishan G, Macdonald AM, Rao MS, Gooddy DC, et al. (2014) Using Environmental Tracers to Understand the Response of Groundwater Resources in Nw India to Sustained Abstraction. In Proc. of 41st International Conf. of International Association of Hydro-geologist (IAH-2014) on Groundwater: Challenges and Strategies during Sep. 18-19, 2014. at Marrakech Morocco.

11. Lapworth DJ, Krishan G, Rao MS, MacDonald AM (2014) Intensive Groundwater Exploitation in the Punjab-an Evaluation of Resource and Quality Trends. Technical Report. NERC Open Research Archive, BGSUK, OR-14-068, p: 34.

12. Lapworth DJ, MacDonald AM, Krishan G, Rao MS, Gooddy DC, et al. (2015) Groundwater recharge and age-depth profiles of intensively exploited groundwater resources in northwest India. Geophysical Research Letters 42.

13. Rodell M, Velicogna I, Famiglietti JS (2009) Satellite-based estimates of groundwater depletion in India. Nature 460: 999-1002.

14. Macdonald AM, Bonsor HC, Rao MS, Krishan G, Steenburgen FV, et al. (2013) Groundwater Topologies in the Indo Gangetic Basin, In: Proc. of International Conf. on Advances in Water Resources Development \& Mangement held at PU, Chandigarh during Oct. 23-27, 2013.

15. Macdonald AM, Bonsor HC, Krishan G, Rao MS, Ahmed KM, et al. (2014) Groundwater in the Indo-Gangetic Basin: Evolution of Groundwater Typologies. In Proc. of 41st International Conf. of International Association of Hydro-geologist (IAH-2014) on Groundwater: Challenges and Strategies during Sep. 18-19, 2014.

16. MacDonald AM, Bonsor HC, Taylor R, Shamsudduha M, Burgess WG, et al. (2015) Groundwater Resources in the Indo-Gangetic basin- Resilience to climate change and abstraction. British Geological Survey Open Report, OR/15/047, p: 63.

17. Gautam SK, Maharana C, Sharma D, Singh AK, Tripathi JK, et al. (2015) Evaluation of groundwater quality in the Chotanagpur plateau region of the Subarnarekha river basin, Jharkhand State, India. Sustainability of Water Quality and Ecology 6: 57-74.

18. Krishan Gopal, Rao MS, Kumar CP (2014) Estimation of Radon concentration in groundwater of coastal area in Baleshwar district of Odisha, India. Indoor and Built Environment.

19. Krishan G, Rao MS, Kumar CP (2015) Radon Concentration in Groundwater of East Coast of West Bengal, India. Journal of Radioanalytical and Nuclear Chemistry. 303: 2221-2225.

20. Singh S, Singh C, Kumar K, Gupta R, Mukherjee S (2009) SpatialTemporal Monitoring of Groundwater Using Multivariate Statistical Techniques in Bareilly District of Uttar Pradesh, India. Journal of Hydrology and Hydromechanics 57: 45-54.

21. Singh SK, Srivastava PK, Gupta M, Mukherjee S (2012) Modeling mineral phase change chemistry of groundwater in a rural-urban fringe. Water Sci Technol 66: 1502-1510.

22. Singh SK, Srivastava PK, Pandey AC, Gautam SK (2013) Integrated Assessment of Groundwater Influenced by a Confluence River System Concurrence with Remote Sensing and Geochemical Modelling. Water Resource Management 27: 4291-4313.

23. Singh SK, Srivastava PK, Singh D, Han D, Gautam SK, et al. (2015) Modeling groundwater quality over a humid subtropical region using numerical indices, earth observation datasets, and X-ray diffraction technique: a case study of Allahabad district, India. Environmental Geochemistry and Health 37: 157-80.

24. Kim AG, Cardone CR (2005) Scatterscore: a reconnaissance method to evaluate changes in water quality. Environ Monit Assess 111: 277-295.

25. Liou SM, Lo SL, Wang SH (2004) A generalized water quality index for Taiwan. Environ Monit Assess 96: 35-52.

26. Sargaonkar A, Deshpande V (2003) Development of an overall index of pollution for surface water based on a general classification scheme in Indian context. Environ Monit Assess 89: 43-67.

27. Tsegaye T, Sheppard D, Islam KR, Johnson A, Tadesse W, et al. (2006) Development of chemical index as a measure of in-stream water quality in response to landuse and land cover changes. Water, Air, and Soil Pollution 174: 161-179.

28. Tiwari AK, Singh AK (2014) Hydrogeochemical investigation and groundwater quality assessment of Pratapgarh district, Uttar Pradesh. Journal of the Geological Society of India 83: 329-343.

29. Krishan G, Khanna A, Singh S, Singh RP, Ghosh NC (2016) Water quality index of groundwater in Haridwar district, Uttarakhand. Water and Energy International 58: 55-58.

30. Tyagi SK, Datta PS, Pruthi NK (2009) Hydrochemical appraisal of groundwater and its suitability in the intensive agricultural area of Muzaffarnagar district, Uttar Pradesh, India. Environmental Geology 56: 901-912.

31. Singh S, Ghosh NC, Krishan G, Galkate R, Thomas T, et al. (2015) Development of an Overall Water Quality Index (OWQI) for Surface Water in Indian Context. Current World Environment 10: 813-822.

32. CGWB (2009) Ground Water Brochure of Muzaffar Nagar District, UP, India.

33. Stigter TY, Ribeiro L, Dill AMMC (2006) Application of groundwater quality index as an assessment and communication tool in agroenvironmental policies-Two Portuguese case studies. Journal of Hydrology 327: 578-591.

34. Tiwari AK, Singh PK, Mahato MK (2014) GIS-Based evaluation of water quality index of groundwater resources in West Bokaro coalfield, India. Current World Environment 9: 843-850.

35. Singh S, Krishan G, Ghosh NC, Jaiswal RK, Thomas T et al. (2015) Designing and Planning of Groundwater Monitoring Network. In: Proceedings of National symposium on Hydrology jointly organized by IAH, NIH, Roorkee and CWC, New Delhi during 22-23 December, 2015 at New Delhi p. 25. 